\title{
Mass Media, Mass Culture, and the Public Sphere
}

\section{Paul Rutherford}

Craig Calhoun, ed., Habermas and the Public Sphere (Cambridge and London: MIT Press 1992).

James L. Braugham, The Republic of Mass Culture: Journalism, Filmmaking, and Broadcasting in America since 1941 (Baltimore and London: Johns Hopkins University Press 1992).

Robert J. Donovan \& Ray Scherer, Unsilent Revolution: Television News and American Public Life (New York: Cambridge University Press 1992).

Janet Wasko and Vincent Mosco, ed., Democratic Communications in the Information Age (Toronto: Garamond Press 1992 and Norwood: Ablex Publishing 1992).

Kathleen Hall Jamieson, Dirty Politics: Deception, Distraction, and Democracy (New York \& Oxford: Oxford University Press 1992).

Steven C. Dubin, Arresting Images: Impolitic Art and Uncivil Actions (London \& New York: Routledge 1992).

Cathy Schwichtenberg, ed., The Madonna Connection: Representational Politics, Subcultural Identities, and Cultural Theory (Boulder, San Francisco, \& Oxford: Westview Press 1993).

Sourcebook: Jürgen Habermas, The Structural Transformation of the Public Sphere: An Inquiry into a Category of Bourgeois Society, translated by Thomas Burger with the assistance of Frederick Lawrence (Cambridge: MIT Press 1989).

Politics is every where these days. The rampant materialism of the Reagan Years has been succeeded by rancorous contention and angry commitment. I'm not just talking about the ordinary politics of government and party, though that continues to fill the newscasts and the newspapers. Rather I'm referring to the way politics has intruded upon other realms of life, whether the home, the workplace, popular culture, the arts, or academe. We live through successive waves of disputes, few of which are satisfied to anyone's satisfaction. All around us we see signs of fragmentation, polarization, cynicism, and a lot of anger. Voters don't trust politicians, certainly not to deliver on their promises. Gays and lesbians, African-Americans and Canadian aborigines wage identity politics to accentuate and celebrate their sense of difference. Quebec nationalists wait in the wings to play that same brand of politics on a much grander scale at the expense of the Canadian nation-state. Exhibiting the photographs of Robert Mapplethorpe or planning a performance of the musical Show Boat excites the political juices, albeit for very different reasons. A Senate hearing over the merits of prospective Supreme Court justice Clarence Thomas makes sexual harassment an issue of moment throughout the business world. The so-called 'Clayoquot Compro- 
mise' in British Columbia enrages eco-warriors throughout America who demand the protection of an old growth forest from apparently rapacious loggers and their political lackeys. An odd assortment of radicals rage against the legacy of sexism, racism, and homophobia, occasionally against classism and ageism as well. An equally mixed group of traditionalists cries out for 'family values' or denounces 'political correctness' or rushes to defend one 'canon' or another. The Yuppie, in short, has left centre stage to the Militant.

It won't surprise that academics in a variety of disciplines have begun to turn out books which shed light upon the history and the style of this present obsession. Three of the works under consideration here (by Braughman, Donovan and Scherer, and Wasko and Mosco) focus chiefly upon media and communications; another three (by Jamieson, Dubin, and Schwichtenberg) concentrate mostly on discourse and audience. I intend to appraise these books in the light of a particular theory of 'the public sphere' outlined thirty years ago by the German philosopher Jürgen Habermas. His theory has recently been celebrated and criticized in the last of the books under consideration: a recent collection of essays edited by Craig Calhoun. My purpose might seem to offend against the conventions of reviewing, since it imposes upon the arguments of the authors an alien framework of ideas. (The name Habermas is almost completely absent from six of the seven works reviewed.) Certainly it means I won't attempt any detailed appraisal of the wealth of detail and comment in any one of these books. It also means I will appear cavalier in my opinion of what's good and bad in their arguments. But Habermas supplies a way to bring together and to critique the disparate findings of these works. I also hope the exercise will demonstrate just how useful Habermas' insights are to understanding the meaning and practice of democracy nowadays and in the past.

I doubt that Habermas is familiar to all readers, so let me briefly introduce the man and his views. Jürgen Habermas is a Professor of Philosophy at the University of Frankfurt who won renown after 1970 for his work on communicative action. Largely unnoticed in the English-speaking world was his first book, The Structural Transformation of the Public Sphere, born as a postdoctoral thesis (required for German professors) and first published in German in 1962. This historical and philosophical work was grounded in the theories of the Frankfurt School, especially its critique of mass culture, although its novel approach to liberalism and democracy apparently upset both Max Horkheimer and Theodor Adorno. In The Structural Transformation Habermas charted the birth, the elaboration, and the eventual degeneration of what he called the bourgeois public sphere over the course of the previous three centuries.

By the public sphere Habermas meant a place "made up of private people gathered together as a public and articulating the needs of society with the state." (176) He saw the community divided between a 'Private Realm' composed of the civil society of commodity exchange and the domestic space of the family and a 'Sphere of Public Authority' where was arrayed the monarch, any parliament, and the state apparatus. (30) Crucial to his theory was the recognition that the public sphere belonged to this Private Realm, though the public sphere served a political function which meant it played a mediating role between the individual and government.The nature and well-being of the public sphere depended upon two attributes: its commitment to what 
Habermas termed 'rational-critical debate,' where equals used reason and argument to reach consensus, and the degree of popular participation, both its openness to the whole citizenry, and the involvement of such citizens in the process of debate.

This sphere grew up in the eighteenth century, first in Britain, partly out of the world of letters, and was called into being by a politicized press. At first it was limited largely to property-owning males, which meant the public sphere was actually an exclusive, even elite institution defined by gender and class. The move toward mass democracy during the course of the nineteenth century opened the public sphere to more and more elements of the population, so that by the early twentieth century this sphere came to incorporate roughly all adult persons, however unequally. Unfortunately what was lost in this transformation was both rational-critical debate and true participation. The rise of social welfare meant the apparatus of the state invaded civil society and turned people into clients. The new dominance of the mass media, and the elaboration of mass culture, turned active citizens into passive consumers. Instead of reason determining politics, negotiation amongst competing, organized interests determined decision-making in democracies, leaving to the supposed public the choices of acclamation, acquiescence, or occasionally rejection. The discourse of advertising and public relations where opinion was managed and moulded had become the dominant form of communication by the second half of the twentieth century. The crisis for democracy was how to overcome this degeneration, how to recreate a public sphere now open to all but still committed to reason. The gloomy tenor of the last third of The Stuctural Transformation suggests Habermas wasn't very hopeful of success, which of course fitted nicely with the pessimism of the Frankfurt School. It is how to evaluate the public sphere in the age of television that most interests me in this review essay.

Craig Calhoun provides an excellent summary of Habermas' views in his introduction to Habermas and the Public Sphere. That book of essays grew out of a conference held in September 1989, occasioned by the first English translation of The Structural Transformation. Calhoun invited a variety of specialists from "history, the social sciences, literature, communications, and philosophy" (viii) to deliberate the virtues and defects of Habermas' insights. He also managed to get Habermas himself to attend and participate. The papers, some "Further Reflections on the Public Sphere" by Habermas, and a bit of the commentary, Calhoun published as Habermas and the Public Sphere.

Like nearly all such collections, readers will find essays they like or dislike depending upon their particular experiences and disciplines. Personally I was disappointed by the three essays on "Public Communications" by Nicholas Garnham, Michael Warner, and Benjamin Lee, because they seemed more interested in fighting other battles than in debating Habermas' original formulation. Likewise I found it difficult to fathom the reasoning behind the essays of two philosophers, Thomas McCarthy and Seyla Benhabib, which may well be a reflection of my own ignorance. On the other hand my understanding of Nancy Fraser's "Rethinking the Public Sphere: A Contribution to the Critique of Actually Existing Democracy" confirmed my view that a politics that is self-consciously 'correct' is a recipe for paralysis. She posits a public sphere so open and so nebulous, the plaything of 'subaltern counter- 
publics' (123) and every conceivable brand of discourse, that it could only collapse under the weight of its own absurdity.

No matter: Habermas and the Public Sphere is an excellent compilation of different views. Habermas' "Reflections" alone are invaluable, especially his brief clarification of "the discourse-centered concept of democracy." (448-450) Beyond that, I was especially impressed by the six essays grouped in the section "Historical Publics." There, for instance, David Zaret and Keith Michael Baker offer revisionist interpretations of the birth and nature of the public sphere in seventeenth-century England and eighteenth-century France respectively. Geoff Eley brings together material from social history, feminist scholarship, and Antonio Gramsci, to update and refine the idea of the public sphere as a way to understand nineteenth-century politics in Europe. Equally fascinating is Mary Ryan's "Gender and Public Access," where she charts how women's entry into politics in the nineteenth century transformed the meaning of 'publicness' in the United States.

But I was most intrigued and amused by Michael Schudson's contribution,"Was There Ever a Public Sphere? If So, When? Reflections on the American Case." Although located in the first section under "Philosophical Models," Schudson concentrates on investigating the "good old days' back before TV debauched minds, a time when American politics was supposedly full of meaning. What he finds is that actual voter participation in elections has waxed and waned over the years: thus "there was a sharp decline in voter turnout from the 1880s to a low in the 1920s." (148) What he doesn't find are many examples of 'rational-critical political discourse,' whether in the taverns, on the hustings, or in the press. Instead he points to the signs of gossip, the importance of communal ritual, and the role of propaganda in times past. All of which is a marvellous antidote to the nonsense that, for example, Neil Postman has popularized in his anti-TV diatribe Amusing Ourselves to Death (though Schudson himself doesn't single out this romantic). Schudson concludes with what I take as some wise words:

I find the concept of a public sphere indispensible as a model of what a good society should achieve. It seems to me a central notion for social or political theory. I think it is also enormously useful as a model that establishes a set of questions to ask about politics past and present.... If I have used my questions more as a club than a beacon, I have done so to dispel the retrospective wishful thinking that beclouds too much contemporary political and cultural analysis. Our place in the world is different from that of eighteenth-century or nineteenth-century Americans, but not, I think fallen. (160-161)

James Baughman certainly avoids any 'retrospective wishful thinking' in The Republic of Mass Culture, though his concluding remarks on the information age are pessimistic. Based largely on secondary source material, his survey is a traditional kind of historical narrative that will be most useful to readers who want the facts about what happened when, and how, to the mass media in the United States over the course of the past fifty years. His account suffers a bit from the sin of all such textbooks one damned thing after another, lots of examples, anecdotes, and statistics, none of which receive much close attention. No sophisticated or complicated theory informs this narrative: instead he presumes the existence of a marketplace in which the rise 
of television and the search for profit provoked a cycle of challenge and response that brought a transformation in the media as an institution. So he charts the rise and fall of the TV networks as the dominant force in communications, the retarded adjustment of newspapers to TV's pre-eminence, and the way movies moved to the margins, at least until VCRs allowed Hollywood to win back 'some of the Lost Audience.' (208) He balances this admitted 'organizational bias' (xiv) with astute comments on the products of the media, be they sitcoms or disco or blockbusters, as well as on the habits of the audience. Thus The Republic of Mass Culture is very informative, and very easy to read, but you come away from it wondering what the whole phenomenon means to American life and culture.

Strange as it may seem, I get the impression that the series editor was also a bit dismayed by Baughman's reticence. In his forward, Stanley Kutler claims the book "offers the raw material for a critical analysis of the phenomenon." (ix) The questions Kutler poses are all worthwile to understanding just what "the republic of mass culture' means. Have the media worked to 'threaten or enhance our cultural diversity?' Does their impact lead to 'a homogenization of politics and culture?' Do the news media 'have a biased political stance?' Are we overwhelmed by' a host of 'pseudo-events' à la Daniel Boorstin? 'Have we lost contact with the reality of substance?' Make up your own mind.

Baughman does supply a few hints, however. He consistently doubts the power of the media, and especially of television, to shape either minds or events. He accepts the findings of ethnography about the sovereignty of diverse audiences, though he spends little time explaining how that works in practice. His account makes clear that however abundant the number of media outlets they served best the tastes and interests of the affluent mainstream: he suggests, for example, that the voices of African-Americans were only heard sporadically in the press, movies, and television even up to the 1980s. He can be both critical and cynical about the achievements of the news media, especially television news, which he believes boasts an inflated sense of its own importance (even though most people don't watch it, and rarely pay attention to it when they do) that belies its mostly mediocre or poor record. His concluding paragraph suggests that things have 'fallen,' or at least gotten a bit worse in the past fifty years:

In the end, Americans lived in an essentially imaginary 'information age.' The excessive mediation and superficiality of most dailies and TV news programs left many with the barest sense of the world about them. Viewers typically finished watching a TV news program without remembering its major points. TV electoral reportage, political scientist Eric A. R. N. Smith concluded in 1989, "was entertaining but not very informative" and had contributed nothing to Americans' political knowledge since the 1960s. A more bitter Ben Stein observed, 'It's the information age and no one knows anything.' (221)

I wish Baughman had allowed himself an afterword to speculate more broadly about the significance of his findings. His observations seem to confirm the worst fears of Habermas' story of degeneration.

Perhaps one shouldn't fault James Baughman because he set out to write a book about the media as an institution. But two veteran journalists, Robert J. Donovan 
(New York Herald Tribune and Los Angeles Times) and Ray Scherer (NBC news) did claim to tackle the public import of TV news in Unsilent Revolution. Their presumptions about the power of TV news stands in striking contrast to Baughman's doubts: they simply declare that TV news transformed the political process "from top to bottom." (ix) Instead of insight though, all too often they serve up tired clichés about TV news which do not effectively explain how that phenomenon shaped 'American Public Life.'

Unsilent Revolution is divided into two sections on the history and significance of television news in America. The first section deals with twelve episodes, from the exit of Joe McCarthy in 1954 to the coverage of the Ethiopian famine in 1984, "when television news changed the course of events and built or destroyed the careers of public figures." $(x)$ That approach avoids dealing with the ordinary routine of news production, though it does provide readers with a lot of trivia about assorted journalists, their equipment, and their derring-do. The next section, entitled "Ongoing Impact," looks at how TV news has conditioned the institutions and practices of government as well as changed print journalism. That section ends with a glance at television's coverage of Tianamen Square, the fall of the Berlin Wall, the Persian Gulf War, and the failed Russian coup, called "the climax of roughly four decades of television news." (308)

Overall Unsilent Revolution presents a contradictory appraisal of the effects of TV news. The authors seem overly impressed by the power of television images to move people to take action, whether for good or ill. Running through their account is a presumption that actually showing the audience what's happening has often had the effect of furthering democracy, whether that meant popularizing Civil Rights in the early 1960s, sponsoring domestic opposition to the Vietnam war at the end of the decade, or bringing down Richard Nixon in the mid-1970s. Their final words celebrate a grand potential, "the new democratizing power of global television." (318) At the same time they lament (but who doesn't) the obsession with "sound bites and image making" (ix) in American politics. Indeed their treatment of the political import of TV relies heavily upon the analogy of the theatre. So we're told that "the White House press conference under Kennedy took on the air of a matinee, the idol in solitary command of the wide stage." (169) Later the authors cite Elizabeth Drew's claim that the Reagan White House "established the Presidency as theatre." (185-86) Apparently his handlers understood (and here they quote Hedrick Smith) that TV politics "is not rational but emotional." (187) That's democracy?

Nowhere do the authors supply a close account of what a newscast was like. They don't explore whether it offered the clarity, logic, and substance which might make the newscast a tool of rational or critical discourse. Nor do they worry about who watched TV news or what viewers did with the images and information offered beyond supplying a few anecdotes. By and large they leave the impression that American viewers are a passive lot who merely play out the role of consumers in national politics. In short, Unsilent Revolution is a superficial history of one source of cultural power which neglects to treat those two vital dimensions of the text and the audience in any careful fashion.

The title of the collection of essays by Janet Wasko and Vincent Mosco, Demo- 
cratic Communications in the Information Age, seems to promise a much more incisive look at the news media. Maybe that's why I found this the most disappointing of all the books reviewed. Yes, editor Wasko does spell out what she calls "the crux of democratic communications": "who owns the technology, who controls it, and who has access to it. In short, who presses the buttons?" (4-5) The best of the essays by Peter Bruck, Sean Cassidy, and Marc Raboy, collected in Part IV, "Social Movements and Media Strategies," do explore how open the media system is (or was) to radical opinion and groups. Bruck looks closely at ambiguity and contradiction in the reporting of the cruise missile tests in Canada to show how alternate voices can find expression in the stories of the mainstream press. Cassidy discusses how Greenpeace managed "to exploit the contradictions within the capitalist media to present alternatives to the dominant worldview." (172) Raboy surveys thirty years of media history in Quebec to highlight the themes of resistance and struggle, given a peculiar expression because of Quebec's sense of difference within North America.

But, unfortunately, the other essays suffer from a plethora of sins: naiveté and tautology (Ingunn Hagen on democratic communication), outdated theory (Mark Schulman on scholarship), reductionism (Kusum Singh on Reagan and Ghandi, or Mashoed Bailie and David Frank on Orientalism), blinkered vision (Dwayne Winseck on CNN), a lack of specifics (Giovanni Cesareo on privacy and secrecy), excessive brevity (Deanna Campbell Robinson on music), irrelevance and triviality (Douglas Kellner on public access TV, or Fred Lonidier on socialist photos), and so on. When the actual public enters the picture, and that's very rare in this book, I get the feeling they are little more than cultural dopes and dupes. So Kusum Singh tells us, "The majority of people, in turn, are mobilized as spectators to be titillated and as 'human resources' to be shaped, stored, and exploited." Such a broad and elitist generalization is woefully out-of-date. Altogether this is a very thin book, short of research and lacking in sophistication, that just doesn't answer the questions Wasko has posed.

What I find missing in these books on media and communications is present in the studies of discourse and audience, which may signal where the most exciting work is being done these days. The communications scholar Kathleen Hall Jamieson set out in Dirty Politics to explain the increasing public disenchantment with political campaigns and more generally political life in the United States. Initially she focuses upon the much-maligned campaign of 1988, and in particular the infamous series of Republican attack ads that, playing on the image of the black man as criminal, made Willie Horton a name known to millions of voters. Later she looks at news coverage, political advertising, and election practices over the course of the past generation and even back into the nineteenth century. A final chapter surveys the quality of argument in election campaigns between 1960 and 1988 to conclude, surprising as it may seem, that the 1980 campaign was the best from the standpoint of democratic politics. Throughout, she employs textual analysis, focus group reports, the findings of cognitive psychology, narrative theory, and the concepts of political science to enrich her account of what happened and why it happened. My main complaint with her analysis is that it bounces around so much, from one issue or campaign to another, 
that at times I find it difficult to follow her train of thought. Perhaps here I suffer from the historian's instinctive yearning for a clear, preferably chronological narrative?

Although Jamieson makes no reference to Habermas, her investigation rests upon an ideal of political speech very similar to his notion of rational-critical discussion. She identifies the key components of democratic debate as argument, engagement, and accountability. By 'argument' she means the testing of views, where participants marshall facts to explain their statements. What she terms "engaged discourse" requires an individual or a party "takes a position, provides evidence to justify that position, and differentiates the position from that of the opponent." (223) Accountability means a candidate is accessible to the press and voters, and that candidate is responsible for any views that are aired under his or her name. Out of this process should come at best agreement, though in any case some knowledge that allows the rational voter to safely predict how a politician will perform once in office. She feels this last result applied in 1980 where the campaign had "informed the public about Reagan's positions and forecast his presidency." (254)

Now Jamieson recognizes that such an ideal has never been fully realized for any length of time in the long history of American politics. "Since the founders, sloganeering - not substance — has been the stuff of politics." (9) But what she claims is that the conventions and the nature of television, notably its visual power, have worked to undermine democratic debate since the 1950s. Assertion, not argument, all too often characterizes political speech. Indeed the dominant form of communication in elections has become political advertising where well-crafted images and claims are used for self-promotion as well as launch an attack and justify a smear. Negative ads work best, it seems, because they play upon voter's fears: she carefully tracks the impact of the story of Willie Horton, told first in ads and later reiterated in news shows, to demonstrate how it fixed in people's minds an impression of Dukakis as soft on crime. Obviously TV news provides little relief: its penchant for sound bites also privileges assertion; its focus on the horse-race downplays issues of substance; and its fascination with images sometimes lets the ads set the news agenda. In the process the public gets turned into spectators, perhaps "cynical and detached" (167), but often seduced or manipulated.

Dirty Politics, in short, confirms the initial pessimism of Habermas. Her book identifies the chief villain as advertising. It finds the cause of voter cynicism and the apparent malaise of present-day politics in the way political speech has been transformed by the self-interest of politicians and newspeople. It pleads the cause of "a discourse that argues rather than asserts, seeks the common rather than private good, relates a candidate's past to his or her promises and those to governance, grants the good will of all parties to the dialogue, and engages the issues raised by others while being engaged by them as well." (11)

What the book doesn't explore, however, is whether such 'engaged discourse' will alone serve the needs of the public sphere. Her account, like that of Habermas, leaves little room for the power of art and performance and style, all of which employ a different logic of symbols and metaphors to elicit a response from voters. Put another way, the striking images and the word play of advertising work their magic because they do reach out to all sorts of people. There are hints of this in some of the 
contributions to Habermas and the Public Sphere. So Benjamin Lee, following on the later work of Habermas, notes the existence of distinct structures of communicative action, each with their own claims to validity, such as "the world-disclosing functions of art and literature." (410) Michael Warner talks about how important the art of display - of body, of 'iconicity,' of goods - has become in modern societies. He even suggests that what he calls "the discursive genres of mass publicity" have encouraged "a massive shift toward the politics of identity," (399) where issues of status reign supreme. But, like Habermas, Warner sees this more as a problem, almost an illness of the public sphere than an attribute of any public sphere.

By contrast, Stephen Dubin deals directly with the symbolic power of art in public life. His Arresting Images focuses on the recent wave of controversy over 'impolitic art,' again largely in the United States, meaning the work of Andres Serrano (notably his 'Piss Christ') or Dread Scott ('What Is the Proper Way to Display a U.S. Flag?'), the Mapplethorpe exhibition, and the crusades of men like Jessie Helms and the Reverend Donald Wildmon. Dubin, a sociologist, takes his lead from the work of Emile Durkheim who argued that battles always occurred over visible deviance and "the definition of acceptable expression." (10) Early on, Dubin posits a set of preconditions for confrontations over art: a fragmented and polarized community, suffering widespread malaise; art works "which address volatile, unsettled issues;" and contested public spaces. (38) Of crucial importance was the re-emergence during the early and mid-1980s of a species of critical art, quite unlike the self-absorbed work previously common. The new art embodied the imagery of alternate voices (feminist, gay and lesbian, African-American, and the like) who directed their irony or fury against racism, sexism, homophobia, bourgeois decency, excessive consumption, militarism, ultrapatriotism, and the other apparent sins of the Reagan Years. The creation and exhibition of this art was often subsidized by public monies, notably through the National Endowment for the Arts which became a focal point of the controversy. All of which was sufficient to inspire what Dubin calls 'moral entrepreneurs' to demand the suppression of radical art and restrictions on public funding. Arresting Images details a wide range of major and trivial squabbles around the themes of race, religion, patriotism and sex, homosexuality and AIDS, before concentrating on the moral entrepreneurs and the reactions of artists plus the struggle over the NEA.

I am most interested here in what Dubin has to say about the art itself. "Images can intensely compress complex ideas and sentiments," he writes. "They often project what Walter Benjamin called 'aura,' an elusive, charismatic and sometimes haunting presence." (3) What upset so many traditionalists was that the critical art indulged in "symbolic transgressions:" the works broke down so-called "natural categories" such as the sacred and the profane, "chaste and polluted, masculine and feminine, in and out, public and private." (5)

In the case of Serrano's "Piss Christ," sacred imagery is mixed with profane bodily waste products (or "the sacred and the endocrine," as one critic charged), With performance artist Karen Finlay the confusion is over ingestion and elimination: she daubs the outside of her body with chocolate; she mashes canned yams over her buttocks, a region of the body from which they would normally be expelled. And 
Robert Mapplethorpe's photographs disturb the peace in two regards. His homoerotic depictions challenge the sexual hierarchy, and his portrayals of White and Black men together also contest the racial hierarchy. (5)

Here was postmodernism with a radical edge.

Traditionalists took offense at this celebration of what seemed to be the bizarre and the ugly. They treated such art as a challenge to their values as well as a symbol of the changes that were destroying their vision of American society. The ways in which this art evoked the anxiety of conservative protesters was illustrated by a pamphlet distributed at the time of the controversy over Dread Scott's "What is the Proper Way to Display the American Flag?"' in Chicago in 1989:

Carrying the imprimatur of the Illinois Veterans of Foreign Wars, the handbill was entitled 'You remember the REAL America.' It reminisced to when 'riots were unthinkable,' 'ghettos were neighborhoods,' and 'you weren't made to feel guilty for enjoying dialect comedy.' It also recollected 'when a boy was a boy, and dressed like one [and] a girl was a girl and dressed like one,' and 'when everybody didn't feel entitled to a college education.' (112)

There are problems with Dubin's work. He insists on recounting so many squabbles that his argument sometimes gets lost in all the detail. He avoids talking about what constitutes art, although he appears to regard that chimerical quality of authenticity as the chief criterion of legitimacy. And thus predictably Dubin nearly always lines up with the artists against their detractors. But Arresting Images does amount to a rebuttal of the one-sided insistence on the place of rational discourse in the public sphere. Art, and such lesser forms as advertising, can play a significant role in debate by exploiting people's fears and hopes to an extent that no amount of logical argument can match. In particular they work to honour and to dishonour values, institutions, and people in ways that can affront or excite, evoking nostalgia or idealism that conditions the response of citizens even when confronted by news or editorials. Any model of the public sphere which neglects that fact will remain incomplete.

Amongst the other 'lesser forms' of art is entertainment, and the last and wildest book in my collection, The Madonna Connection, focuses upon the political meanings of a person who is arguably the most significant superstar in this postmodern moment. This book of essays belongs in the camp of Cultural Studies, that burgeoning field of analysis which has made popular culture such a hot topic throughout the humanities in North America in the recent past. Now I'm sure The Madonna Connection won't be to everyone's taste: it's chock-full of wacky speculation (Patton on 'subaltern memory'), learned deconstructions of fleeting images (Scott on the video Like a Prayer), much theorizing (Schwichtenberg on "Madonna's postmodern feminism"), and multiple allusions to Jean Baudrillard, Michel Foucault, and other French luminaries. The essays 'read' Madonna from the standpoint of race, gay and lesbian culture, feminism, and postmodernism. Ironically Madonna as a performer often gets lost in the zealous search to discover what her music and videos really mean - and, in particular, to answer the question, Is Madonna 'real' or just a clever mix of changing images, notably Pribram's superb account of the documentary Truth or Dare? Historians will be especially bemused by the awesome present-mindedness 
of so many authors - thus there are surprisingly few references to past superstars, even Marilyn Monroe or Elvis Presley (a partial exception is Seigworth's confusing attempt at 'cognitive mapping'). Only two of the authors, David Tetzlaff on "Metatextual Girl" and Susan Bordo on "Material Girl," fully recognize that Madonna herself is a historical object, that in her short career she has changed her persona dramatically to adjust to changing fads and fashions. But I find such work exhilarating because it stretches the mind - the mix of theoretical rigour and imagination evident in so many of these essays makes the book fascinating.

The leitmotif I see running through The Madonna Connection is the contrast between mass culture and popular culture. Here I follow in the footsteps of John Fiske, another Name often referenced in the book, whose Reading the Popular and Understanding Popular Culture have attained much fame and notoriety in the realm of Cultural Studies. Mass culture is what they do (referring here to the images Madonna and her people create); popular culture is what 'we' do (referring to the meanings consumers create out of these images).

Madonna is a miracle of contemporary marketing, the 'master' and 'mistress' of self-promotion, of entertainment and advertising (don't forget that music videos, where Madonna has excelled, grew out of the genre of commercials). Always she appears in charge, whether she is being stalked (Like a Virgin), or sneering at Kevin Costner (Truth or Dare), or the victim of a mock rape (see her Sex book). The way Madonna always exudes power is closely analyzed by Pribham. Throughout her career, Madonna has appropriated images from the fringe, be they pornography, drag, gay and lesbian sex, sadomasochism, voguing, or gender-bending, and packaged these to appeal to audiences in the mainstream. Tetzlaff's piece is especially fine on the issue of Madonna as an ever renewing commodity. (Personally I was struck by just how different is Madonna's 'look' in the various photographs presented in the book.) She always transgresses, reverses or confuses the 'natural categories' (see Dubin again), to shock and excite her fans. She constantly evades efforts to pin her down, to reveal what is or may be her authentic self. Instead she relishes exposure, publicity, attention, where she can display her body and her imagery. A number of authors are struck by the wisdom of that evocative comment by her companion-ofthe-moment Warren Beatty in Truth or Dare where he declares, "Turn the camera off? She doesn't want to live off-camera, much less talk. There's nothing to say off-camera. Why would you say something if it's off-camera. What point is there of existing?" It is all this which makes her the unequalled postmodern star, a well-designed collection of simulacra, to employ Baudrillard's terminology.

But does this also make her a queer icon, a multicultural hero, a true feminist in short the champion and instrument of alternate voices in America? Or does this make her a tramp and a bimbo, pandering to the low tastes of the debauched masses? That all depends. Roseann Mandziuk's superb "Feminist Politics and Postmodern Seductions" warns feminists against "the allure of escape and ephemerality" (183) embodied in the kind of postmodern excess represented by Madonna. Her defiant ambiguity ensures that her meanings will be created by her various audiences, whether teenage 'wannabes' or 'dirty old men.' So, after viewing Justify My Love, one gay critic enthused, 'Never has a pop star forced so many of the most basic and 
necessary elements of gayness right in the face of this increasingly uptight nation with power and finesse.' (119) But Lisa Henderson, the lesbian activist who cites that comment in her essay, has her doubts because she cannot discount Madonna's ambivalence, her lack of authenticity. Similarly Nakayama and Peñaloza in "Madonna T/Races" carry out an ethnographic study to discover that there's no single black or Hispanic or Asian reading of Madonna's music videos, since so many different factors determined how their subjects decode her personas. The three authors Laurie Schulze, Anne Barton White, and Jane D. Brown, who call Madonna a 'Low-Other,' (!) probably get it right when they write, "There is no way to settle, once and for all, the argument about whether Madonna's texts are feminist. That issue depends on the uses to which these texts are put and on the contexts in which they are interpreted and inscribed." (31) What I do find striking, though, is the way Madonna suits the present fad of identity politics: she is used by all manner of so-called disempowered groups, be they the wannabes or the sadomasochists, as an embodiment of their difference and defiance.

Which brings me back to Habermas and the public sphere. Recall those twin attributes of well-being, the kind of discourse and the degree of participation. Madonna communes with her fans through visual images, a form of art (a low form if you wish) which honours and dishonours certain symbols and institutions. Her texts are open, accessible to a wide range of people and interpretations, so wide that she is able to bridge the gaps that divide a fragmented America. She and these texts are the subject of rational-critical discourse carried on by journalists and scholars who spy in her performances all manner of political references (see, in particular, E. Ann Kaplan's piece on "Madonna Politics"). More generally, the phenomenon of Madonna illustrates how popular culture has become, at one level, 'politics by other means,' a way of dealing with questions of power and status and difference in a public sphere where the recognized, normal brand of politics is so unsatisfactory to so many people.

I cannot resist closing without a comment on the style of The Madonna Connection and a few other works, however. Some of the authors of that collection are very self-conscious about their role as 'Madonna scholars,' perhaps in part because the tabloid-TV show 'Inside Edition' exposed such academics to public mockery. Indeed Schwichtenberg, Nakayama \& Peñaloza, Henderson, Kaplan, Bordo, and Seigworth all make comments about the role and mission of cultural critics. A few of the authors in Democratic Communications in the Information Age (see, for example, Schulman or Bruck) see critical theorists working out strategies for a wider public assault on the bastions of media power. Kathleen Hall Jamieson clearly would like her book to inspire a general clean-up of campaign discourse. Stephen Dubin does want Arrested Images to represent the justice of the artist's cause. Such dreams of intervention in the public sphere are once again fashionable these days (especially given the past success of feminist scholars).

I only wish that good writing, or just clear writing, was also fashionable. On the whole the style adopted by the authors of the book-length studies was at least understandable - and Baughman's The Republic of Mass Culture is a pleasure to read. Not so of all too many of the essays in the other three compilations. It took 
multiple readings to try to extract what Nicholas Garnham and Michael Warner were trying to say in their confused contributions to Habermas and the Public Sphere. Peter Bruck's otherwise fine essay in Democractic Communications in the Information Age was sadly marred by large doses of jargon. And some of the authors of The Madonna Connection seemed to write in a way which had no pity on their public. What do authors expect a reader to make of such sentences?:

Madonna-as-social-disease is a site where disparate discourses converge: discursive strands of liberal and socially concerned humanism, the conservative religious Right, and feminism form a strange alliance against the low-Other, Madonna. (Schulze, White, \& Brown, 23)

I use the term proper here in the sense used by Jacques Derrida (1981) and Michel de Certeau (1988), referring to the structural place in which strategic engagement means performing critique in (rather than outside of) the rhetorical terms of the hypostatized culture and where tactics, although potentially effective in recircuiting and altering such rhetorics, exist largely as momentary deflections of the hypostatized rhetoric. (Patton, 83)

This reinscription in the plural expands the range for a coalitional politics not determined or fixed by foundationalist frames. Thus, one could 'come out' and participate in a range of identities - such as a lesbian heterosexual, a heterosexual lesbian, a male lesbian, a female gay man, or even a feminist sex-radical. (Schwichtenberg, 141)

Madonna thus presents a voice that has clearly - if not without a fair amount of controversy - theorized its own speech, becoming one of those "pained and disgruntled subjects, who are also joyous and inventive practitioners [beginning] to articulate our critique of everyday life' (Morris 1990, 41). (Seigworth, 301)

Yes I know how unfair it is to select a sentence or two out of a much larger work (I've been the victim of this as well). But that's the only way I can briefly suggest the utter arrogance of some authors. At best, they are showing off; at worst, they are muddled thinkers. Not only do they write in a way which closes the door on the educated reader, they make it impossible for students and academics (who remain their chief audience) to be sure just what they are trying to say. This kind of excess makes a mockery of the ideal of rational-critical discourse. It is surely time for academics to try to strive for clarity, especially if they have aspirations to inform a wider public. Else, presumably, they'll have to leave the task to the ad-makers, newspeople, and Madonnas who apparently are so effective in sending their images into the public sphere. 